\title{
THE DYNAMIC OF MALAY ISLAMIC LAW The Rise and Practices of Adat Bersendi Syarak, Syarak Bersendi Kitabullah in Jambi
}

\author{
Subhan MA. Rachman \\ UIN Sulthan Thaha Saifuddin, Jambi - Indonesia | subhan.mar@gmail.com \\ Fuad Rahman \\ UIN Sulthan Thaha Saifuddin, Jambi - Indonesia | fuad_rahman33@yahoo.com
}

\begin{abstract}
This study aims at determining the position of Islamic law in the culture of Malay society in Jambi, Sumatera. The obvious facts in the previous studies about Islamic law and culture in Malay Sumatera is heavy emphasis on Minangkabau of West Sumatera with its matrilineal culture and traditionalist-modernist tension. In contrast, Jambi, which is adjacent to Minangkabau region, is starkly different. Jambi culture does not recognize matrilineal culture, except for Minangkabau people migrating to Jambi, nor experience such a tension. This is evidenced from interviews and library sources alike. Interviews were undertaken from several members of traditional leaders including some of the decendents of Jambi Malay Kingdom. As the result, even though there was a was among devotees of each of the laws, Islamic law (Syarak) and customary law in greater Malay Sumatera, the aphorism "Customary laws are based on religious laws; religious laws are based on the Holy Book" unites them, and becomes the living law that rules Muslim society in Jambi from the past until present day.
\end{abstract}

Keywords: Malay, Islamic law, customary law, Sumatra.

\section{Introduction}

There are several research objects on Islamic law in Sumatra that relate to cultural aspects such as marriage, inheritance, and even criminal laws. Similarly, there are numerous researches on Islamic law in Sumatra is the interaction of Islamic law and Malay culture. Among 
the interesting aspects of Malay culture is Minangkabau of West Sumatra for obvious reasons. ${ }^{1}$ Minangkabau is the largest matrilineal culture in the world, and there was intensive interplay and even tension between local matrilineal custom, widely known as adat with Islam in its course of history. ${ }^{2}$ The introduction of Islamic law has created somewhat a new feature of both sides, which is specific in Minangkabau society. The interaction of Islam and Minangkabau culture has created a well-known aphorism of "Adat Basandi Syarak, Syarak basandi Kitabullah," which simply means "Customary laws are based on religious laws; religious laws are based on the Qur'an." This aphorism is a revision of previous aphorism signifying the primary role of customary law alongside of Islamic law in Minangkabau society. ${ }^{3}$ It can be inferred from the aphorism that there was negotiation among the supporters of customary law and supporters of Islamic law on how to implement law and order in Minangkabau society. In later development, there was tension and conflict in Minangkabau between traditionalists who insisted on preserving syncretic Islam and the modernists who asserted a more orthodox version of Islam. This culminated in an armed conflict which recorded as Padri War. ${ }^{4}$

However, this is not the only face of Islam in Sumatra. Jambi Malay society, which is located in southeast border of Minangkabau, has a different story. Although Jambi Malay people also subscribe to the aphorism of superiority of Islamic law over customary law interestingly, its story is a sharp contrast of matrilineal Minangkabau in many ways. Certainly, Jambi Malay society is patrilineal. Thus, In Jambi

\footnotetext{
${ }^{1}$ Heinzpeter Znoj for instance states that not much is known about the highlands of Jambi, whereas many sources are available about the coastal sultanate and Minangkabau. See Heinzpeter Znoj, "Sons versus Nephews. A Highland Jambi Alliance at War with the East India Company, ca. 1800," Indonesia, 65 (1998), pp. $97-$ 121.

2 See for instance, Taufik Abdullah, "Adat and Islam: An Examination of Conflict in Minangkabau," Indonesia, 2 (October 1966), pp. 1-24; Abd A'la, “The Genealogy of Muslim Radicalism in Indonesia: A Study of the Roots and Characteristics of the Padri Movement," Journal of Indonesian Islam, 02, 02 (December 2008), and Zaim Rais, "Respons Kaum Tuo Minangkabau terhadap Gerakan Pembaharuan Islam," in Dody S. Truna and Ismatu Ropi (eds), Pranata Islam di Indonesia: Pergulatan Sosial, Politik, Hukum, dan Pendidikan (Jakarta: Logos Wacana Ilmu, 2002).

3 Yasrul Huda, Contesting Sharia: State Law, Decentralization and Minangkabau Custom (Leiden: Leiden University Repository, 2013), p. 57.

${ }^{4}$ A'la, 'The Genealogy of Muslim Radicalism in Indonesia, p. 285.
} 
Malay Society, application of Islamic law is somewhat smoother that it is in Minangkabau context. It is not only applied in negotiation but also applied as the guide to implement the customary laws. Thus, the aphorism of "Customary laws are based on religious laws; religious laws are based on the Qur'an" arguably applies more consistently in Jambi. Tensions occurred in Jambi is not as sharp compared to Minangkabau. Jambi society believes that customary should be based on syarak because the aphorism is not only a symbol of the dynamic between Islamic and customary law, but also the rule that must be obeyed. However, the relation between customary and syarak or between the supporter of each of the laws is not always in harmony. Different point of views in understanding the aphorism becomes the reasons of the controversy. Syarak supporters believe the textual meaning of the aphorism, whereas customary supporters tend to offer different interpretations. This article intends to discover the tradition and historical development of Islamic Law in Jambi with special focus on how the concept of culture and syarak is perceived, and how the integration between culture and Syarak is negotiated and agreed upon.

\section{Law Tradition in Sumatra with Special Reference to Jambi}

Sumatra is a part of Indonesian Archipelago which is inhabited by the majority of Melayu tua (Proto-Malay) or Melayu Muda (DeuteroMalays). ${ }^{5}$ The term "Malayu" is derived from the Malay empire that had once existed in Batanghari river area, Jambi. As a matter of fact the use of the term Melayu extends to the outside of Sumatra following the territorial of Srivijaya including Java, Kalimantan and Malay Peninsula. Indeed, it can be said that the people from Malay peninsula are originated from Sumatra. ${ }^{6}$

Malay Kingdom finally capitulated and came under the influence of Srivijaya. Initially, Jambi was considered as a minor trading and raiding state on the region surrounding Melaka Strait. Srivijaya took control Jambi in 683 and in its course of its reign once became the capital of Srivijaya due to its Batang Hari River strategic location. ${ }^{7}$ In around 1275, Kertanegara, a King of Singasari from Java raided Jambi

\footnotetext{
5 Peter Bellwood, "Indo-Malaysians of the Last 40,000 Years," Prehistory of the IndoMalaysian Archipelago: Revised Edition (Canberra: ANU Press, 1997), pp. 69-95.

${ }^{6}$ Ibid.

7 Nicholas Tarling (ed.), The Cambridge History of Southeast Asia Volume 1, From Early Times to c. 1800 (Cambridge: Cambridge University Press, 1993), p. 175.
} 
and remained under its authority until Adityawarman, the king of Minangkabau absorbed Jambi into his kingdom. ${ }^{8}$

As Islam started to penetrate Indonesian archipelago during the $12^{\text {th }}$ century along trade route, Malay people were among the first indigenous people who embraced Islam. Islam was not only embraced by lay people but also by Malay courts including the sultanate of Johor, Perak, Pahang, and the sultanate of Siak.. In Jambi, the spread of Islam is facilitated by the establishment of Jambi Sultanate. This sultanate initially rose in late 15 century and slowly developed its power for quite some time. The existence of Jambi Sultanate become effective during the reign of Sultan Abd al-Qahhar (reign 1615-1643). ${ }^{10}$ It was only in this $17^{\text {th }}$ century that an independent sultanate ruled effectively in Jambi. It signed trading cooperation with foreign traders, including Europeans with pepper as its main commodity. ${ }^{11}$

Gradually, Malay people had to wrestle with Islam which has its set of law and regulation in a situation where they had already own custom. It turned out that instead of discarding one value at the expense of the other, Malay people tended to integrate Islamic law to their customary law with mixed result. The rules related to law could not be separated to the local culture. The enforcement of the Islamic Law that was integrated to the social culture was always enshrined as well as practiced in customary rules that symbolized in the form of aphorism such as "memetik bungo setengkai"-for the community of Jambi and Minangkabau — which means a ban on marrying two sisters. This aphorism is in accordance with Islamic law of marriage which prohibits polygyny marriage that combines two siblings. However, another aphorism saying "idak baik melanggar baso", which means it is prohibited for a man to marry his mother's cousins is problematic because Islamic law does not prohibit such a marriage. Likewise, in the area of criminal law, local people ensured that the Islamic criminal law might be able to adapt to the customary rules. They used the term

8 Robert Cribb and Audrey Kahin, Historical Dictionaru of Indonesian (Lanham: The Scarecrow Press, 2004).

${ }^{9}$ In addition to indigenous people, European colonial powers also made ways for the migration of notably Sri Lankan and South Africans to fill important positions in the kingdoms such as being a harbor officials, scholars, and judges.

10 Ali Muzakkir, "Kisah Orang Turi dalam Sejarah Islam di Jambi," Thaqafiyyat, 14:2 (2013), p. 299.

${ }^{11}$ Cribb and Kahin, Historical Dictionary of Indonesian, p. 203. 
'tikam bunub' to express the rules of qisas as in Islamic criminal law, although all forms of customary violation would be penalized in form of fine or 'pampas' in Malay term. ${ }^{12}$

Given the prevalence of Islamic law in Malay Sumatra, it is perceptible that the tradition of Islamic law in Sumatra is a legal tradition that cannot be separated from social reality and local cultural values. Moreover, each culture competes to be the first area that embraced, and applied the rule of Islam. Minangkabau society as well as Jambi and Riau Society claim that their customary laws are based on religious laws (syarak); and Syarak are based on the Holy Book, the Qur'an. ${ }^{13}$ This phenomenon brings the opportunity to each of the group of the society to prove their existences.

Through this study and based on interviews with some Islamic and traditional leaders, it can be declared that the controversy of the privilege of the historical originality of the aphorism "Customary laws are based on religious laws; religious laws are based on the Qur'an" which has become the reference of the law in Sumatra, is contestable. It should be contested that the aphorism was originated from Minangkabau. The very reason for that is the fact that Minangkabau culture tends to be matrilineal. This is in sharp contrast with Islamic law which is originally patrilineal in nature. it is aptly assumed that the aphorism is more suitable with Jambi culture which tends to be patrilineal.

This could be seen from, among other things, the governmental system of the period. The Jambi Sultanate was governed by a man named Ahmad Salim known as Datuk Paduko Berbalo. Moreover, If he was from Minangkabau, then what matters in Minangkabau society is customary law at the expense of any other rivaling law, including Islamic law. Thus, it can be also assumed that the integration between religion and culture in Minangkabau only firmly took place after Padri war as late as late $19^{\text {th }}$ century. In contrast, while the aphorism had

12 Aulia Tasman, "Memahami Adat Lamo di Wilayah Jambi," paper presented in 'Seminar Adat Melayu Jambi' (2014), p. 2.

13 According to Jeffrey Hadler, this aphorism "syarak basandi kitabullab" is a later insertion to aphorism "adat basandi syarak", 1950s to be exact. However, it could be a statement of a long established practice. See Jeffrey Hadler, Sengketa Tiada Putus: Matriarkat, Reformisme Agama dan Kolonialisme di Minangkabau (Jakarta: Freedom Institute, 2010), p. xii. 
occurred in Jambi since the reign of Datuk Paduko Berbalo's Crown Prince that had honorific title called Orang Kayo Hitam.

Regardless all the controversy, this study aims to show that the tradition of Islam and Islamic law in Sumatra, especially in Jambi, are legal traditions that have always been integrated to local culture. As a matter of fact Malay Society- especially those living in Malay peninsulahas always been related to Islam.

\section{Jambi's Interpretation of "Customary Laws are Based on Religious Laws; Religious Laws are Based on the Qur'an"}

Since law is seen as the primary manifestation of Islam, Malay Muslims tried their best to apply Islamic law in their context. They decided not to abandon their custom altogether. Instead, as elsewhere in the archipelago, they supplant Islamic law to the existing custom and tradition. The result, however, was differed from one place to another. In Jambi, the situation is the same. The efforts of inserting Islamic law not only took place in society, but also in constitutional law of Jambi kingdom. Based on the history of Islamic kingdom in Sumatra, the integration of Islamic Law (Syarak) and local custom was firstly in form of a codified regulation by Jambi Malay Islamic Kingdom in the $16^{\text {th }}$ century under leadership of Datuk Orang Kayo Hitam. He integrated syarak and custom as codified law known as Undang Jambi. ${ }^{14}$ This Undang Jambi was influenced by the advent of Islam to the Malay Kingdom of Jambi. Islam substantially influenced customs which initially only based on norms that was believed to be hereditary. With Islamic penetration, these newly converted Muslims revised the custom to suit Islamic law they believed. ${ }^{15}$ Meanwhile, in the western part of Jambi region which was not yet converted to Islam, aphorism of "adat bersendi alur, alur bersendi patut, patut bersendi kebenaran" still existed. ${ }^{16}$

In early $17^{\text {th }}$ century, when Islamic Kingdom of Jambi penetrated and ruled the western part of the land, the enforcement of Islamic law could reach the whole Jambi region. In the process of this conquest of the western area, a king's representative was sent to Muaro Masumai,

\footnotetext{
14 Suaidi Asy'ari, "Managing Islamic Public Space: Responses of Sumatran Malay Muslims toward 'Neo-anti Bid'ah' Movement," Journal of Indonesian Islam, 7: 2 (2013), p. 221.

15 Tasman, Memahami Adat Lamo, p. 2.

${ }^{16}$ Which means that custom is based on decency and decency is based on truth.
} 
Bangko, though the political power in Bangko at that time was still influenced by the federal custom system shared among several local political leaders; Depati Setio Rajo, Depati Setio Nyato dan Depati Setio Rajo. ${ }^{17}$ Since this federal system was politically and militarily weaker than the kingdom of Jambi, Bangko and other areas under its rule in the western part of Jambi could be easily overpowered by Jambi Malay Islamic Kingdom. The area of Muaro Masumi which was a part of the custom federal system once ruled by Depati Setio Rajo had to submit the power of Tumenggung Kabul Dibukit, the Jambi Malay Kingdom at the $16^{\text {th }}$ century. ${ }^{18}$

However, in the newly conquered western Jambi the customary rules was still prevalent although Islamic values was acknowledged. Since then, there was an ambivalence in the implementation of law in the western part of Jambi. The societies who had been accustomed to customary law for a long time were reluctant to fully implement Islamic law. However, they politically accepted the rules determined by Jambi Kingdom. Since the establishment of the Kingdom of Jambi in 1526, the area of Kerinci and Merangin in the western part of Jambi were under new influence of by 'Taliti', Jambi customary law while traditionally in Kerinci and Marnagin had implemented 'Undang', a customary law originated from Pagaruyung from 1347 until 1526. The interplay between Taliti and Undang is best described by the following local saying: "Undang turun dulu, taliti mudik dari tanah pilih, undang tibo dulu taliti tibo kemudian, undang datang bertali gial, taliti tibo bertali tajuk, undang talanjuo kile taliti talanju mudik."19 It roughly means that Undang came first (from Minangkabau) whereas Taliti from the chosen land (which is Jambi). Undang and Taliti integrated into one. While

17 Pusat Penelitian Sejarah dan Budaya, Sejarah Kebangkitan Nasional Daerah Jambi, (Jakarta: Proyek Penelitian dan Pencatatan Kebudayaan Daerah, Pusat Penelitian Sejarah dan Budaya, Departemen Pendidikan dan Kebudayaan, 1979), p. 27.

18 Aulia Tasman, Membongkear Adat Lamo Pusako Usang - 39, http://tasman1959.blogspot.co.id/2014/09/membongkar-adat-lamo-pusako-usang-39.html, accessed on 27 November 2017.

${ }^{19}$ Undang is assumed as a customary from Minangkabau while Teliti is a part of Islamic law. The assumptions is now hundred percent correct because of two reasons: First: Minangkabau culture and Jambi culture are integrated into Malay culture under the authority of Malay Kingdom. The use of local language is similar as it is written in Undang duo pulub, which was not only used in Minangkabau terminology but also inother Malay ethnics in and beyond. Second, if Malay language is taken into consideration, it can be said that Malay ethnics were originated from Jambi. 
Undang came from Minangkabau of Pagaruyung, the government is native to Jambi.

Predictably, it had not to wait very long when complication and tension happened. As reported by Tasman, difficulties occurred in applying criminal customary law, Pagaruyung criminal law or Tanah Pilib criminal law. To resolve the tension, customary meeting was held in Bukit Sitinjau Laut in 1530. In the By implementing Taliti in this area, then the two legal systems existed at the same time in the same area. Admittedly, there was a different punishment systems between Taliti and Undang. On that note, local people says: 'Apo kato Teliti, apo pulo kato Undang, cukil mato pembunub kato Taliti, cukil mato kerbau kato Undang, potong tangan pencuri kato Teliti, potong tangan kambing kato Undang", which translate: punishment of murder is death according to Taliti, and fine in form of buffalo according to Undang. Punishment of theft is cutting theif's wrist, and fine in form of goat according to Undang. This showed what Undang said would be very different from what Taliti said which ended in difficulty to decide. ${ }^{20}$

Another example was in a murder case. According to Taliti, the heirs of the victim had two choices to punish the murderer. The murderer might pay the fine (diyat) while according to Undang or Kisas, the murdered would get death penalty, so the murderer would face difficulty, local people use the term 'beremas mati, tidak beremas mati' for this situation. Although the perpetrator had gold or money for the fine, he still might get death penalty on behalf of customary law. It was an eye for an eye. In Pucuk Jambi territory on the other hand, in terms of murder case, the murderer not only had to pay for the fine, but he might also reconcile with the heirs of the victim. Indeed, in order to unify the two laws, Taliti and Undang, It was suggested to hold the meeting in Bukit Sitinjau Laut.

Nowadays, governmental system in the western part of Jambi still runs the customary law while in Jambi province where two parts of Jambi unified, the customary law is ran in the western part of the province and natural law is ran in the east part of the province. Thus, The Jambi Malay Custom Institute faces difficulties in applying the customary law. The basic principal of "Customary laws are based on religious laws; religious laws are based on the Qur'an would be difficult to implement since not all citizens in Jambi nowadays are Muslims

20 Tasman, Membongkar Adat Lamo Pusako Usang. 
adalah perbedaan adat, (kull al-balad qiyâmubu bi al-âdab) karena tiap negeri itu berdiri dengan adat, (faizâhakamtum bain an-nâs 'an tabkumu bi al-'adl) jika engkau menghukum konplik di antara manusia, maka tentukanlab status bukum dengan adil, (wa'amma 'âdah al-Islam muqâbalah bi as-syari) ketentuan adat dan syarak dalam Islam saling melengkapi. jikalau terkata pada bukum, syarak namanya, jika tertegah pada syarak, jabil namanya, jikalau tiada tertegah dalam syarak dan tiada terkata di dalam syarak, bukum adat namanya. maka itulah yang dipakai pada segala negeri Islam, sebagaimana firman Allah ta'ala (wa man lam yabkum bi mâ anzala Allâh fa ulầik hum az-zâlimun, fa ulầika hum alkâfirun, faulầika hum al-fâsiqun, fa ulâika bum al-munâfiqun) dan barang siapa yang tidak berbukum sesuai dengan ketentuan Allah ta'ala maka orang itulah yang sangat zalim lagi kafir, lagi fasik, lagi munafik, dan orang tersebut masuk ke dalam golongan orang yang kafir dan kekal di dalam neraka jahannam."23

In other words, customary law is the first thing to be considered, according to Ahmad Rasyid, secretary of Malay Custom Institution, an institute for preservation of custom in Jambi. ${ }^{24}$ The basic principle in customary law is "induk undang" or main law which consists of five pillars. One of the pillars is known as "titian teras betanggo batu", which is the law as the result of integrating syarak and custom based on The Qur'an and Al-Hadith. Then, to protect customary law, Malay custom Institute was founded. The institution focuses on the determining the whole procedures of implementing the customary rule. ${ }^{25}$ The existence of customary law or customary rules as a non-formal rule practiced by the community in Jambi certainly has a strong formal foundation so it can be used as a guide for society today.

\footnotetext{
23 Ibid., p. 57.

${ }^{24}$ Interview with Ahmad Rasyid, 10 June 2016.

25 According to Muchtar Agus Cholif, theoretically, there are several terms that relate to customary law; custom institution, custom society, and customary law. Firstly, custom institution is the organizer of the customs in the village in accordance with the customary law embraced and held on its territory. Second, custom society, the unity of a society that has the completeness of personnel for stand alone, i.e. has legal unity, ruler, and community based on the same rights on the land. Third customary law, is the overall law that determine the decision of the legal practitioners who have authority and influence that can be adhered. Agus Cholif, Undang Duo Pulub Adat Melayu Jambi, (Jambi: Lembaga Adat Melayu Jambi, 2009), p. 12.
} 


\section{Syarak and Adat in Contemporary Jambi}

Based on this historical background, contemporary Jambi Muslims understand the interplay between Islam and their customary law. In course of history there were tensions between proponents of syarak and proponent of adat. For the former group, syarak should be applied categorically, whereas for the latter group adat should be well implemented. However, the difference between both camps is surprisingly trivial.

Syarak or Islamic law means "a set of rules based on the revelation of God, and the Sunnah about human behavior that a Muslim recognized and believed to be valid and binding for all its members." 26 This definition of Islamic law is in line with what is understood by the Malay people in Jambi, but they are more likely to use the term syarak (commonly known as religious law). For instance, Sulaiman Abdullah, the head of MUI (Majelis Ulama Indonesia Indonesian Ulama Council) of Jambi27 states that before the advent of Islam, Jambi Society has had an established custom as the heritage of their ancestors. When Islam came and was incorporated in local custom, it was accepted and become the law. Jambi people then understood what is said to be the custom that would be part of syarak or Islamic law from the Qur'an and Sunnah. This hybrid law dealt with civil and criminal matters. On that basis, the compliance of the community to the customs is getting more powerful because it was believed to have been originated from syarak (Islamic law).

Similar statement is also expressed by head of MUI of Sarolangun, Suhar AM. ${ }^{28}$ He states that In Malay tradition, Syarak is the divine law

26 The word set (seperangkay), according to Amir Syarifuddin is the rules formulated in detail and have the power to bind. The Pharse 'based on the revelation of Allah and the Messenger'shows that the rules was unearthed from the regulation and based on the revelation of God, and the Sunnah, or known as Syarîah. The phrase 'about buman behavior that mukallaf 'shows that Islamic law only governs to the human who becomes the subject of the law. The legal is valid and has the power toward the people who are convinced of the truth of revelation andsunnah, i.e. Muslims. As a matter of fact, the meaning of Islamic law is the same as fiqh. The study of Islamic law includes two things. First, the study about the detailed regulations which is amaliah and must be be followed by Muslims in religious life. Second, the study on conditions and procedures and systematic effort in producing a detailed regulation device which is ushûl figh or "the methodology system of fiqh." See Amir Syarifuddin, Ushûl Figh (Jakarta: Logos Wacana Ilmu, 2001), p. 5.

${ }^{27}$ Interview with Sulaiman Abdullah, 29 Maret 2016.

${ }^{28}$ Interview with Suhar AM, 20 September 2015. 
that must be obeyed although it has already become a part of Jambi custom. It is not surprising if the society often use the term syarak and custom interchangeably. Syarak becomes the guide in legal practice of the community because it is considered as the law. If it is valid according to Syarak, then it would be valid according to custom. Both of the law are integral and hard to be separated. These two statements indicate that the existence of syarak is undeniable in Jambi. However, the term syarak is mostly used by those knows very well about Islamic law, whereas lay people are more likely to use the term tradition or custom. Consequently, the community did not immediately leave the custom because generally, the values embodied in the custom is not considered contrary to the values of syarak.

\section{Meaning of 'Adat' in Jambi}

Surprisingly, a proponent of Adat Datuk Ramli Raden, one of the descendent of Sultan Thaha Saifuddin, ${ }^{29}$ states that adat by no means contradictory to syarak. He says:

"Bagi orang Jambi adat ado tigo macam biso dio berupo bukum, akblak apo kebiasaan. Pertamo, adat berupo bukum suruban dan larang pantang ukurannyo apo kato syarak dan apo kato adat. Macam; munub, maling, zina, dan lain-lain. Keduo, adat berupo kelakuan atau akblak ukurannyo pantas apo idak, patut apo idak, macam; sembahyang dak pake kepiah apo kain, macam itu jugo nyelawat orang meninggal dan lain-lain. Ketigo, adat berupo kebiasaan bae bole dibuat apo idak macam nuju bulan, maco surat Yusuf dan Maryam waktu hamil dan lain-lain."

This translates that Malay Jambi society believe that there are three definitions of adat (custom); First, adat (custom) is something to be upheld by the community in the form of obligation or prohibitions. This type of adat is measured by Syarak and adat. It regulates the law of killing, stealing, adultery and so on. Second, custom is something which is simply a habit or tradition which is practiced in a form of etiquette, with propriety or decency as the basic principal. For instance, this concept of custom regulates the rule of wearing skullcap and holsters for men, wearing a black skullcap and so on. Third, adat (custom) refers to anything done or prohibited, such as; celebration during seventh month of pregnancy by reciting the Quran, especially chapter of Yusuf and Maryam.

${ }^{29}$ Interview with Datuk Ramli Raden, 21 March 2016. 
At a glance the interpretation Datuk Ramli Raden on adat is that adat encompasses all practices in Jambi society. He does not question the origin of each adat. For him, adat and syarak is equally the same because syarak, to some sorts, has been absorbed into one entity with the name of adat. This assumption is backed up by other adat proponent, Datuk Raden Jayo, another the descendent of The King of Jambi, ${ }^{30}$ when he says:

"Sebelum agama Islam tibo di Jambi, masyarakat Jambi la punyo aturan berupo adat istiadat, namun sudah Islam datang dan atas perintah Datuk. Orang Kayo Hitam,adat atau tradisi yang ado harus disesuaikan dengan syari'at Islam. Akbirnyo dikumpulkan selurub kerajaan yang ado di sekitar kekuasaan kerajaan Melayu Jambi bingga Pagaruyung Minangkabau untuk menentukan macam mano adat yang sudah ado ko. Keputusannyo adat atau undang yang ado harus diteliti, harus sesuai dengan ajaran Islam. Hinggonyo labirlah seloko 'Undang datang dari Hulu, Teliti dari Hilir'. Maksudnyo, adat yang ado harus sejalan dengan ajaran Islam."

Which translates: "Before the coming of Islam, the Jambi Malay community has had their customary law, but then over the edict of the Jambi sultan of Datuk Orang Kayo Hitam, the customary law existed at that time might be tailored to the principles or values of Islam. To realize that goal, the King of Jambi initiated a summit with the King of Pagaruyung from Minangkabau, since the latter was was not a Muslim. The results of the meeting reflected in the aphorism "Undang comes from upstream, teliti comes from downstream" which means that all existing customs at that time should be verified (carefully) to be integrated with syarak. (Islamic law)".

The similar idea is also expressed Kemas Uzeir, an advisor of Laskar Melayu Jambi, a local adat organization, ${ }^{31}$ he states:

"Syarak dan adat la lamo menyatu dalam adat Jambi ko Sepucuk Jambi Sembilan Lurah, sehinggola orang Jambi lebih arif nan bijaksano menanggapi segalo masalah. Dak pernah kejadian rusuh, dendam kesumat, apolagi orang mudo kurang ajar dengan orang tuo. Yang tuo dituokan yang mudo disayang, yang keci' idak isebut namonyo, yang besa' idak dimbau gelarnyo."

\footnotetext{
${ }^{30}$ Interview with Datuk Raden Jayo, 20 June 2015.

${ }^{31}$ Interview with Kemas Uzeir, 15 July 2015.
} 
This translates: "Islamic law and local custom have long been fused in the Jambi society. On that basis, Jambi people are known as wise community when it comes to dealing with social problems and conflicts. There was never any riots or vengeance (which caused by syarak or adat disputes)."

These three statements reassert the existence of syarak and custom as well as their integration in the tradition of Malay people in Jambi, which brings the aphorism "Undang comes from upstream, teliti comes from downstream." Undang is the indigenous Malay culture which came from Minangkabau and originating from the Malay people in Jambi in the Western region. Meanwhile, teliti is a rule that come from Islamic law brought by Datuk Paduko Berhalo. The aphorism then becomes the principal of the other aphorism which is "Customary laws are based on religious laws; religious laws are based on the Qur'an." Syarak that existed later on, verified the existing customary law, and this kind of practice has been recognized since the time of the Prophet. Many traditions and ignorance were verified by Islam to be legalized or rejected. At that time, syarak was the prevailing law that resolved by religious issues, and the role of the employee of syarak as the representations of the religious group were dominant.

\section{Conclusion}

Islam always manifested in new form when Indonesia is the locus. Jambi is no exception. Although Jambi is patrilineal, several aspects of orthodox Islam needs to be negotiated. Adat, as local customs play significant role in this process. The tradition and historical development of Islamic law in Jambi Sumatra, Islamic law in Sumatra tends to be flexible. Islamic law is able to adapt to the surrounding environment, regardless all the controversy, about the origin of the integration of custom and religion. The aphorism "Customary laws are based on religious laws; religious laws are based on the Qur'an" proves more consistently that tradition of Islam and Islamic law in Jambi Sumatra are legal traditions that have always been integrated to local culture. As a matter of fact Malay Society- especially those living in Jambi has always been related to Islam. In relation to the concept of custom and syarak, custom in terms of Sumatra Malay society does not only mean a recurring habit, but also a culture decorated with ethical legitimacy in which Islamic law play as guiding principle. In 
historical context, this conclusion is recorded by many events which shows prevalence of Islamic law in Jambi. This prevalence is maintained until today, when proponent of syarak and adat in Jambi are on the same boat about this.

\section{References}

Znoj, Heinzpeter. "Sons versus Nephews. A Highland Jambi Alliance at War with the East India Company, ca. 1800." Indonesia, 65, (1998).

Abdullah, Taufik. "Adat and Islam: An Examination of Conflict in Minangkabau." Indonesia, 2 (October 1966).

A'la, Abd. "The Genealogy of Muslim Radicalism in Indonesia: A Study of the Roots and Characteristics of the Padri Movement." Journal of Indonesian Islam, 02: 02 (December 2008).

Rais, Zaim. "Respons Kaum Tuo Minangkabau terhadap Gerakan Pembaharuan Islam." Dody S. Truna and Ismatu Ropi (eds). Pranata Islam di Indonesia: Pergulatan Sosial, Politik, Hukum, dan Pendidikan. Jakarta: Logos Wacana Ilmu, 2002.

Huda, Yasrul. Contesting Sharia : State Law, Decentralization and Minangkabau Custom. Leiden: Leiden University Repository, 2013.

Bellwood, Peter. "Indo-Malaysians of the Last 40,000 Years." Prehistory of the Indo-Malaysian Archipelago: Revised Edition. Canberra: ANU Press, 1997.

Tarling, Nicholas (ed.). The Cambridge History of Southeast Asia volume 1, from early times to c. 1800. Cambridge: Cambridge University Press, 1993.

Cribb, Robert and Audrey Kahin. Historical Dictionary of Indonesian. Lanham: The Scarecrow Press, 2004.

Muzakkir, Ali. "Kisah Orang Turi dalam Sejarah Islam di Jambi." Thaqafiyyat, 14:2 (2013).

Tasman, Aulia. "Memahami Adat Lamo di Wilayah Jambi." paper presented in 'Seminar Adat Melayu Jambi', 2014.

Hadler, Jeffrey. Sengketa Tiada Putus: Matriarkat, Reformisme Agama dan Kolonialisme di Minangkabau. Jakarta: Freedom Institute, 2010. 
Asy'ari, Suaidi. "Managing Islamic Public Space: responses of Sumatran Malay Muslims toward 'Neo-anti Bid'ah' Movement." Journal of Indonesian Islam, 7:2 (2013).

Pusat Penelitian Sejarah dan Budaya. Sejarah Kebangkitan Nasional Daerah Jambi. Jakarta: Proyek Penelitian dan Pencatatan Kebudayaan Daerah, Pusat Penelitian Sejarah dan Budaya, Departemen Pendidikan dan Kebudayaan, 1979.

Tasman, Aulia. Membongkar Adat Lamo Pusako Usang - 39, http://tasman1959.blogspot.co.id/2014/09/membongkar-adatlamo-pusako-usang-39.html, accessed on 27 November 2017.

Harun, Hermanto and Irma Sagala. "Dinamika Model Pemerintahan dalam Masyarakat Melayu Islam Jambi: Studi Kasus Kabupaten Bungo." Kontekstualita, 28:1 (2013).

Dilogo, Ngebi Sutho. Alih Aksara dan Kajian Naskah Silsilab Raja Jambi, Undang-Undang, Piagam dan Cerita Rakyat Jambi, translated by. Syamawi Darahim et.al. Jambi: Department Tourism and Culture of Jambi Province, 2005.

Cholif, Agus. Undang Duo Pulub Adat Melayu Jambi. Jambi: Lembaga Adat Melayu Jambi, 2009.

Syarifuddin, Amir. Ushûl Fiqh. Jakarta: Logos Wacana Ilmu, 2001. 